\title{
Studying the trends in arrivals and prices of onion in Ahmednagar market of Maharashtra
}

R. D. SHELKE, R.V. CHAVAN AND M.M. BHOGAONKAR

Received : 13.06.2014; Revised : 18.02.2016; Accepted : 20.03.2016

\begin{abstract}
An attempt has been made in this study to find out the trends in arrivals and prices of onion, in two market of Ahmednagar and Rahuri. On the basis of major findings of the study, the seasonal indices of arrivals were noticed higher during the month of January to July and highest in the month of March i.e. 127.04, which was lower during August to September and lowest in September i.e. 62.10. For Rahuri market, the arrival indices were noticed higher in the month of February i.e. (153.10) and lower in the month of October (71.00). Regarding price indices, it was highest in the month of December (130.60) and lowest in the month of April (75.10) when the arrival of Rabi onion commences in the market. During November to December, prices of onion were high, indicating scope for producers to plan the storage period, accordingly. The important marketing functions in the marketing of onion are grading, packaging, storage and transportation. At the overall level, the variability in arrivals of onion was 78.26 per cent and 75.03 per cent for Ahmednagar and Rahuri markets, respectively. In the case of the variability in the prices, it was noticed to be 47.72 per cent and 35.45 per cent for 10 years period (2002-03 to 2011-12) in Ahmednagar and Rahuri market, respectively.
\end{abstract}

KEY WORDS : Onion storage, Prices of onion, Seasonal indices

How to cite this paper : Shelke, R.D., Chavan, R.V. and Bhogaonkar, M.M. (2016). Studying the trends in arrivals and prices of onion in Ahmednagar market of Maharashtra. Internat. J. Com. \& Bus. Manage, 9(1) : 49-52.

\section{MEMBERS OF THE RESEARCH FORUM}

Correspondence to:

R.V. CHAVAN, Department of Agricultural Economics, College of Agriculture, Vasantrao Naik Marathwada Krishi Vidyapeeth, PARBHANI (M.S.) INDIA

\section{Authors' affiliations:}

R.D. SHELKE, Department of Agricultural Economics, College of Agriculture, Vasantrao Naik Marathwada Krishi Vidyapeeth, PARBHANI (M.S.) INDIA

Email: rds125@rediffmail.com

M.M. BHOGAONKAR, Department of Agricultural Engineering, College of Agriculture (V.N.M.K.V.), LATUR (M.S.) INDIA 